\title{
Genetic Diversity Analysis of Edel Cocoa Clones Parental Cross Using Maturase K (matK) Gene
}

\author{
Indah Anita-Sari*1), Sobir ${ }^{2)}$, Irvan Faizal ${ }^{3)}$, Agung Wahyu Susilo ${ }^{1)}$, Akhmad Hidayatullah²), \\ and Pingkan Sugianto ${ }^{2)}$ \\ ${ }^{1)}$ Indonesian Coffee and Cocoa Research Institute, Jl. PB. Sudirman 90 Jember, Indonesia \\ ${ }^{2}$ B Bogor Agriculture University, Jl. Dermaga Campus, Bogor, Indonesia \\ ${ }^{3}$ Balai Pengkajian dan Penerapan Teknologi, Kawasan PUPIPTEK, Tangerang, Indonesia \\ "Corresponding author: indah.anitasari@gmail.com \\ Received: 18 September 2017 / Accepted: 26 November 2017
}

\begin{abstract}
Economically, cacao bean products are divided into fine flavor and bulk cocoa. Fine flavor cocoa has white color beans while bulk cocoa has purple color beans. Bean color of fine-flavor cocoa beans is determined by the presence of a double recessive gene which is inherited from Criollo cocoa type. Analysis of the genetic background in this study used maturase $\mathrm{K}$ (matK) gene to ascertain the identity of the genotypes which will be used as a parent in crossing of fine flavor cocoa plants. The study aimed to investigate the genetic background of the promising clones that will be used as a parent in breeding program on fine flavor cocoa based on maturase $\mathrm{K}$ (mat $\mathrm{K}$ ) gene in order to ensure the identity of the genotype that will be used in parent crossing and it had Criollo ancestor. DNA analysis was conducted at Agency for the Assessment and Application Technology (BPPT), Serpong, West Java. DNA analysis was conducted on eight genotypes consisting of four genotypes of fine flavor cocoa (ICCRI 02, DRC 16, PNT 16 and DR 2) and four genotypes of bulk cocoa (MCC 01, MCC 02, Sulawesi 1, and KW 617). The results showed that Maturase K ( $m a t K)$ was one of chloroplast gene which could be used to study phylogenetic and evolution on cocoa. Two primers Mac 02 and Mac 09 were used for amplification of matK gene on cocoa with a rate of homology $99-100 \%$ with position 872 bp for Mac 02 and 1153 bp for Mac 09. The results of the phylogenetic analysis showed that the cocoa genotypes would be used as parent crossing included DR 2, ICCRI 02, DRC 16, PNT 16, MCC 01, MCC 02, Sulawesi 1, KW 617 and HJ 2 tended to have ancestral Criollo as female parent.
\end{abstract}

Keywords: Maturase K, fine-flavor cocoa, genetic variation, crossing parent

\section{INTRODUCTION}

Cocoa plants are classified into three types, namely Criollo, Forastero, and Trinitario. Forastero consists of three groups including Amelonado, Upper Amazona and Lower Amazona (Motamayor et al., 2008). Forastero is the most-used cocoa reaching up to $80-90 \%$ of total cocoa production. Criollo is a type of cocoa which has fine taste, yet it is vulnerable to pest and disease
(Mawardi, 1982). Trinitario is a crossed cocoa plant between Criollo and Forastero which results to excellent vigor variation, characteristics and production (Motamayor et al., 2008). Based on economic point of view, cocoa plants are classified as edel cocoa and bulk cocoa. Bulk cocoa is the one that has fresh purple beans, while edel cocoa has fresh white beans (Anita-Sari et al., 2016). 
Cocoa plants in Indonesia are mostly the breeds of Trinitario cocoa which is the crosses plants between Criollo Venezuella (introduced in 1888) and Forastero Venezuela (introduced in 1880). Cocoa breeding program was done at the first time in 1912 by Dr. C.J.J. van Hall using the selection method to the parental plants in Djati Roenggo cocoa farm, Central Java, Indonesia. The selection method resulted in 12 numbers of cocoa including DR 1 and DR 2. Whilst, DRC 16 is one of the selected plants from the DR 1 illegitimate beans (Marwadi, 1982). Repeated selection was done on edel cocoa population in Penataran cocoa farm, East Java, which resulted in quality cocoa beans genotype of ICCRI 01 and ICCRI 02 which are resistant to pod rot (Suhendi et al., 2004). DRC 15 is an edel cocoa, a quality genotype that is resistant to VSD (vascular streak dieback), obtained from the selection method carried out in Kaliwining Experimental Station which was later renamed with ICCRI 05 (Susilo et al., 2009). Individual selection to Trinintario population planted in 1938 in Penataran cocoa farm was conducted based on several criteria including yield potency, susceptibility to VSD and quality beans (color of the beans). The selection resulted six varieties of cocoa breeds code PNT 8, PNT 12, PNT 16, PNT 17, PNT 18 and PNT 33B (Anita-Sari et al., 2015).

Cocoa breeding program is currently focused on conducting some researches to find for the best edel cocoa that are resistant to pests and diseases especially VSD which has caused huge damage to cocoa farms in Indonesia. The breeding process can be obtained through cross pollination between edel cocoa and bulk cocoa which has strong resistance to pests and diseases. The crosspollinating to obtain edel cocoa with white beans needs parent seeds from Criollo gene for the white gene produced by two pairs of recessive genes. The white gene is inherited from Criollo cocoa (Bartley,
2005). Thus, by knowing the genetic background of parent cross plants from the Trinitario breed which is originally from the Criollo breed, it is expected that the probability to produce cocoa with higher number of white beans since the Criollo brings recessive white gene (aa) is cross-pollinated with the Trinitario (Aa), that gives higher chance to obtaine the aa genotype. The result would be different if Forastero (AA) is used in the experiment, that is likely to produce purple cocoa beans (Aa).

Analysis of cocoa genetic background can be done using genom chloroplast. According to Chase et al. (1993), chloroplast genom is highly suitable to be used for kinship identification in species level. Chloroplast genom (cpDNA) is a paired-DNA that forms circular shape of size 120-160 kb (Didriksen, 2010) which consists of the $r b c L, t r n H-p s b A$ and $m a t K$ genes (Kress et al., 2007; Kalangi et al., 2014 ). The consortium for the barcode of life (CBOL) recommends $r b c L$ and $m a t K$ genes to be used as standard barcodes. The order of nucleotide of the mat $K$ gene produces approximately $1500 \mathrm{pb}$ (Enan \& Ahmed, 2012). Fuse \& Tamura (2000) stated that $m a t K$ gene is one of the chloroplast gene which codes the maturase. The eternal plastid that is most effective to be used in the phylogeny and plant evolution studies. The objective of this research was to investigate the genetic background of the parents clones of the cross edel cocoa based on the maturase $\mathrm{K}$ (mat $\mathrm{K}$ ) gene in order to determine that the genotype of the breeds used in the cross pollination bring the characteristics of Criollo beans.

\section{MATERIALS AND METHODS}

In this study, the genetic materials were collected from the collection of cocoa (Theobroma cocoa L.) germplasm in Kaliwining Experimental Station of Indonesian Coffee and 
Cocoa Research Institute (ICCRI), Jember, East Java, Indonesia. Multiplication of the genetic materials was done using grafting method on the rootstock of plants after reaching the age of 3 months. Good quality scions were used in this study as indicated by brown color in their top parts, and green color in their bases. The plant grafting was done using 2-3 prospective buds. The graft cover was opened after 2 weeks as indicated by the presence of new buds in the upper scion. Graft failure is shown by withered scions or rotten scions. The genetic materials obtained from the process were then brought from ICCRI to Luwikopo Garden, Bogor Agriculture University to make it easier in selecting samples of leaves and in analyzing the DNA. The genetic materials included two types of cocoa plants; bulk cocoa and edel cocoa (Table 1).

Table 1. Genetic meterials used in DNA analysis of $m a t K$ gene of cocoa plant

\begin{tabular}{|c|c|}
\hline Genotype & Pedigree \\
\hline Sulawesi 01 & $\begin{array}{l}\text { Bulk cocoa, exploration result of South } \\
\text { Sulawesi }\end{array}$ \\
\hline MCC 01 & $\begin{array}{l}\text { Bulk cocoa, exploration result of South } \\
\text { Sulawesi }\end{array}$ \\
\hline MCC 02 & $\begin{array}{l}\text { Bulk cocoa, exploration result of South } \\
\text { Sulawesi }\end{array}$ \\
\hline KW 617 & $\begin{array}{l}\text { Bulk cocoa, selection result of TSH } 858 \text { x } \\
\text { Sulawesi } 01 \text { cross }\end{array}$ \\
\hline DR 2 & $\begin{array}{l}\text { Edel cocoa, selection result of Djati Roenggo } \\
\text { Estate }\end{array}$ \\
\hline ICCRI 02 & Edel cocoa, selection result of Penataran Estate \\
\hline DRC 16 & $\begin{array}{l}\text { Edel cocoa, selection result of DR } 53 \text { progeny } \\
\text { in Djati Roenggo Estate }\end{array}$ \\
\hline PNT 16 & $\begin{array}{l}\text { Edel cocoa, exploration result of Penataran } \\
\text { Estate }\end{array}$ \\
\hline
\end{tabular}

DNA analysis was conducted in Badan Pengkajian dan Penerapan Teknologi (BPPT), Serpong, West Java. The DNA of eight cocoa genotypes including four genotypes of edel cocoa (ICCRI 02, DRC 16, PNT 16, DR 2) and four genotypes of bulk cocoa were analyzed in this study.

\section{DNA Extraction and Determination}

The DNA extraction method refered to a modified model of DNA Mini Kit (Plant) Protocol. In the preparation process, genom was extracted by selecting some samples of leaves which were then cut into smaller size around $1 \mathrm{~mm} \times 1 \mathrm{~mm}$ or $0.15 \mathrm{~g}$ to make easier in grinding. Liquid nitrogen was added in the grinding process of the leaves in mortal porcelain. The mashed leaves were then put into 1.5 microtube for vortex processing. The next step was adding $400 \mu \mathrm{L}$ GP1 and $0.5 \mu \mathrm{L}$ RNAse then incubated in a temperature of $65^{\circ} \mathrm{C}$ for 10 minutes. After that, it was added with $100 \mu 1$ GP2 to undergo vortex process until it evenly spread before incubated in ice for 3 minutes. The solvent was then poured into the filter column, centrifuged at $5000 \mathrm{rpm}$ for 2 minutes, and its supernatant was put into 1.5 microtube to be added with GP3 buffer as much as 1.5 times of the supernatant volume. Then, the solvent was moved to the GD column to be centrifuged for 2 minutes at 5,000 rpm twice. After that, the supernatant was left $400 \mu$ l of W1 Buffer was added and centrifuged for 30 seconds. The GD collumn was then brought to 1.5 microtube, added with elution buffer which had been incubated within a temperature of $65^{\circ} \mathrm{C}$ and let sit for 5 minutes, centrifuged for 1 minute at $5000 \mathrm{rpm}$, and then the GD Collumn was thrown away. The result of the extraction was then tested using nano drop in order to determine its DNA quality and quantity per $1 \mu 1$.

The DNA was amplified using 2 pairs of primer which were designed using BLAST program, which results were coded as Mac 02 and Mac 09. Amplification process employed a PCR Takara machine with the total solvent volume of $25 \mu \mathrm{L}$ per reaction which consisted of $12.5 \mu \mathrm{L}$ PCR buffer, $0.5 \mu \mathrm{L}$ primer Mac 09 Forward, $0.5 \mu 1$ primer Mac 09 Reverse 
(or $0.5 \mu \mathrm{L}$ of Mac 02 Forward; $0.5 \mu$ of primer Mac 02 Reverse); $0.5 \mu \mathrm{L}$ Terra Polimerase; $1 \mu \mathrm{L}$ of DNA and $9 \mu \mathrm{L}$ of $\mathrm{ddH}_{2} \mathrm{O}$. PCR amplification was set as follows; 1) predenaturation at $98^{\circ} \mathrm{C}$ for 2 minutes for 1 cycle; 2) Denaturation at $98^{\circ} \mathrm{C}$ for 10 for 35 cycles; 3) Anneling $\mathrm{TM} 57^{\circ} \mathrm{C}$ for 15 minutes for 30 cycles; 4) Elongation at $68^{\circ} \mathrm{C}$ for 1 minute for 35 cycles; and 5) Final elongation for $68^{\circ} \mathrm{C}$ for 1 minute for 1 cycle.

The product of amplification called amplicon was then electrophorized at $0.8 \%$ agarose using $1 \mathrm{X}$ TAE buffer, dyed using loading dye and then soaked into $1 \%$ ethidium bromide for 15 minutes and it was visualized using UV transluminator and digital camera.

\section{Sequencing}

The sequencing process required a mixture of $23 \mu \mathrm{l}$ DNA from the PCR process and $50 \mu \mathrm{L}$ of amplicon. Purification was done to $300 \mathrm{mg}$ gel from the electrophoresis added with DF buffer, and then incubated in 55$60^{\circ} \mathrm{C}$ temperature for $10-15$ minutes. After that, $800 \mathrm{ml}$ of the sample was put into the DF column to be centrifuged at $14.000 \mathrm{rpm}$ for 30 seconds. Then, the supernatant was thrown away, and $600 \mu \mathrm{L}$ of wash buffer was poured and centrifuged at $14.000 \mathrm{rpm}$ for 30 seconds and 2 times repetition. Elution buffer or TE was then added and centrifuged at $14.000 \mathrm{rpm}$ for 30 seconds, and the purification result was analyzed using a nanodrop. The result of the purification or the amplicon from the PCR process was finally sent to the Fist Base for the sequencing procedure.

The result of the sequencing process was analyzed using BLAST program and Clustal Omega. The analysis was done in the homology level and sequenced alignment among the eight genotypes. Kinship analysis was administered using the phylogenetic tree test in Clustal Omega program.

\section{RESULTS AND DISCUSSION}

DNA isolation of the cocoa chloroplasts was done to amplified the target gene that is the maturase $\mathrm{K}$ (mat $\mathrm{K}$ ) found in the chloroplasts. The isolation of the pure chloroplast DNA of the cocoa plants was a challenging task since cacao leaves had smaller cells, and the amount of core DNA in every cell was higher that the cpDNA, besides it also contained high polyphenols which caused the imperfection and absence of restriction endonuclease (REN) enzyme. According to Fatchiyah et al. (2011)), DNA extraction from the nucleous, mitochondria, and other organels is a crucial step through lysis processs and homogenization using extraction buffer or lysis buffer to protect the DNA from any damage.

Total DNA genom from the isolation process can be seen from its quantity and quality using nanodrop. The DNA which had good quality and quantity were then amplified using primer Mac 02 and Mac 09. The electrophoresis from the PCR using 100 volt potential was done for 35 minutes with agarose concentration of aorund $0.8-1 \%$. The agarose gel resulted from the electrophoresis was soaked in etidium bromide $1 \%$ for 15 minutes. Etidium bromide contained fluorescent compound which was chained to the DNA, making the DNA fluorescent inside the agarose gel if it hit the UV light. The PCR mat $K$ gene amplification produced DNA fragments as seen in electrophoregram (Figure 2,3 , and 4).

The visualization of Terra ${ }^{\mathrm{TM}}$ PCR Polymerase product using primer Mac 02 and Mac 09 showed the appearance of DNA matK gene ladders which were the target gene. Primer Mac 02 was found in $872 \mathrm{pb}$ and the primer Mac 09 was at $1153 \mathrm{pb}$. The result of the visualization indicated an effect of agarose concentration used in the experiment on the thickness of the ladders. $1 \%$ concentration 


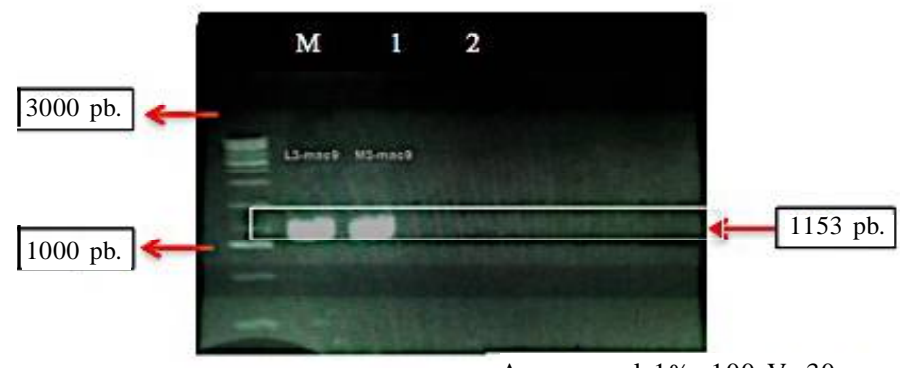

Agarose gel 1\%, $100 \mathrm{~V}, 30$

Notes:

M : Marker DNA $1 \mathrm{~kb}$

Column 1 : MCC 02 - Mac 09

Column 2 : PNT 16 - Mac 09

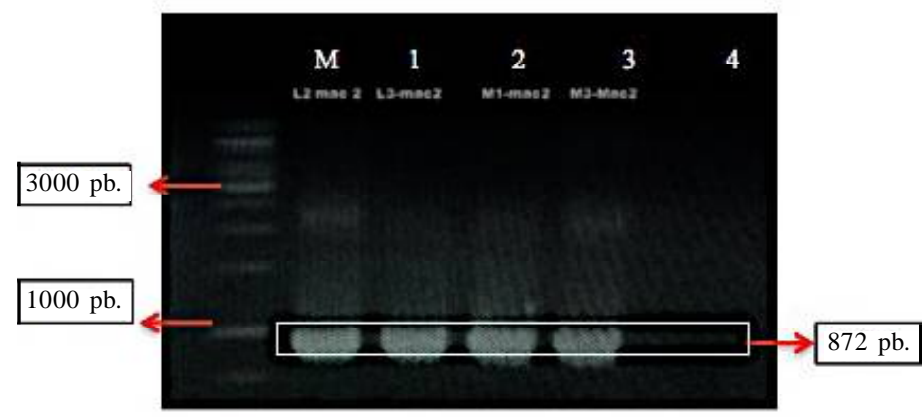

Agarose gel 1\%, $100 \mathrm{~V}, 30$

Notes:

M : Marker DNA $1 \mathrm{~kb}$

Column 1 : KW 617 - Mac 02

Column 2 : MCC 02 - Mac 02

Column 3 : ICCRI 02 - Mac 02

Column 4 : PNT $16-$ Mac 02

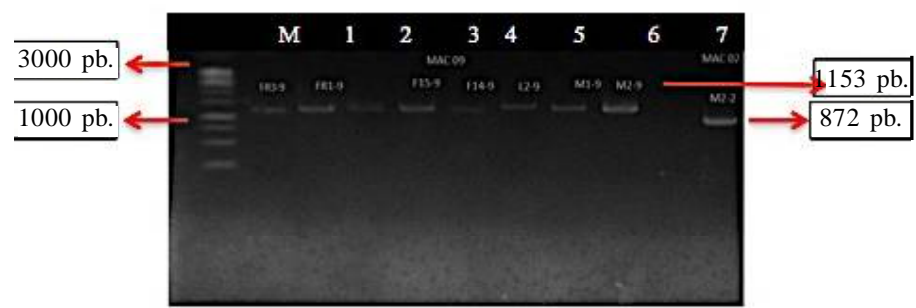

Notes:

Agarose gel 1\%, $100 \mathrm{~V}, 30$

M : Marker DNA $1 \mathrm{~kb}$

Column 1 : ICCRI $02 \times$ Sulawesi $01-$ Mac 09

Column 2 : ICCRI 02 x Sulawesi 01 - Mac 09

Column 3 :

Column 4 : Sulawesi 01 x ICCRI $02-$ Mac 09

Column 5 : Sulawesi 01 x ICCRI 01 - Mac 09

Column 6 : KW 617 - Mac 09

Column 7 : ICCRI $02-$ Mac 09

Column 8 :

Column 9 : DRC $16-$ Mac 09

Figure 1. Product visualization of Terra ${ }^{\mathrm{TM}}$ PCR Polymerase with Mac 02 dan Mac 09 primer on matK area of cocoa plant 
Table 2. Blast result of matK area of cocoa plant

\begin{tabular}{lcccccc}
\hline Description of Theobroma cacao & $\begin{array}{c}\text { Max } \\
\text { score }\end{array}$ & $\begin{array}{c}\text { Total } \\
\text { score }\end{array}$ & Query cover & E value & Ident & Accession \\
\hline Genotype ICS-39 chloplast, partial genome & 2918 & 2918 & $100 \%$ & 0.0 & $100 \%$ & JQ228387.1 \\
Genotype Pentagonum chloroplast, partial genome & 2918 & 2918 & $100 \%$ & 0.0 & $100 \%$ & JQ228386.1 \\
Genotype Stahel chloroplast, partial genome & 2918 & 2918 & $100 \%$ & 0.0 & $100 \%$ & JQ228385.1 \\
Genotype Criollo-22 chloroplast, partial genome & 2918 & 2918 & $100 \%$ & 0.0 & $100 \%$ & JQ228379.1 \\
Chloroplast, partial genome & 2913 & 2913 & $100 \%$ & 0.0 & $100 \%$ & JQ228389.1 \\
Genotype ICS-01 chloroplast, partial genome & 2913 & 2913 & $100 \%$ & 0.0 & $100 \%$ & JQ228181.1 \\
Genotype Amelonado chloroplast, partial genome & 2913 & 2913 & $100 \%$ & 0.0 & $99 \%$ & JQ228380.1 \\
Chloroplast, complete genome & 2907 & 2907 & $100 \%$ & 0.0 & $99 \%$ & HQ336404.2 \\
Genotype ICS-06 chloroplast, partial genome & 2907 & 2907 & $100 \%$ & 0.0 & $99 \%$ & JQ228383.1 \\
Genotype Scavina-6 chloroplast, partial genome & 2907 & 2907 & $100 \%$ & 0.0 & $99 \%$ & JQ2283832.1 \\
\hline
\end{tabular}

of agarose showed thicker ladders than the ones from agarose $0.8 \%$.

Good quality of DNA ladders from the electrophoresis using PCR can be seen from the cleanliness of the ladder. The selected DNA as then sequenced to see the formation of nucleotide base from each ladder according to the primer used in the process. Based on the result, the nucleotides were merged in order from each sequencing of each primer Mac 02 and Mac 09 to form chunked matK gene from each genotype. The merging was done using BLAST program which the pairing results were later manually merged.

\section{Base Nucleotide Order Homology}

The determination of base nucleotide order was carried out using Nucleotide Basic Local Allignment Search Tool (Nucleotide BLAST). Referring to the result of a research done by Imanissa (2016), it was stated that the sequencing result was confirmed using the Blast program (nucleotide blast) in NCBI. This program was used to obtain organism information with similar base nucleotide order to the base nucleotide order of the samples. The homology of base nucleotide order obtained using blastn showed that the $m a t K$ area from the sequencing result had high homology level at $99-100 \%$ in the matK area from the Theobroma cocoa genotype ICS-39, Pentagonum, Shahel, Criollo-22,
ICS -01, ICS-06 and Scavina-6 (Table 2). Base nucleotide order obtained from the sequencing was the matK area of Theobroma cocoa $\mathrm{L}$. (NCBI:2).

\section{Multiple Allignment and Philogenetic Analysis}

Multiple alignment was administered to the sequenced results from two primaries Mac 02 and Mac 09 which had been previously merged. The pairing of the sequencing results of the two primaries using BLAST program were then manually merged based on the base nucleotides pairing order. The multiple alignment was done to eight genotypes and some sequenced area of the matK from several sources such as the ones mentioned by Dermawan (2016) including HJ 2 and sequenced mat $K$ area from a number of cocoa genotypes obtained from GeneBank NCBI. Some of the secondary data used in this study were also obtained from the GeneBank NCBI including Amelonado, ICS-39, Scavina-6, ICS-06, Criollo-22, EET-64, and ICS-01.

The result of the analysis showed that the genotype Sulawesi 1 had some differences from the DRC 16, and it showed an obvious difference between the two nucleotide bases compared to other genotypes. It was found that the other genotypes have the base order AG (adenine-guanine) while Sulawesi 1 has a 
GA (guanine-adenine). The genotype DRC 16 also showed a different base nucleotide from other genotypes for DRC 16 has a TT (thymine-thymine). Whereas, other genotypes have an AT (adenine-thymine). The quality of those bases have been analyzed using a software namely Sequnced Scanner 2.0 which result showed that they were high quality bases. This result goes in line with the ones pointed out by Immanisa (2016) in which it was stated that the Sulawesi 1 had the highest difference in number of the bases compared to other samples.

Phylogenetic analysis was performed based on the sequencing or the order of nucleotide bases from the result of the merge between two primaries. The result of the analysis showed that the genotyes formed three groups. The group I consisted of ICS 06, Sca 6 and ICS 01 with a genetic gap of 0.0. The group II consisted of ICS-39, HJ 2, DR 2, MCC 01, Sulawesi 1, PNT 16, KW 617, DRC 16, MCC 02, ICCRI 02, EET-64 and Criollo-22. Whilst, the group III only consisted of Amelonado.

The result of the phylogenetic analysis showed that cocoa genotypes in Indonesia are DR 2, ICCRI 02, DRC 16, PNT 16, MCC 01, MCC 02, Sulawesi 1, KW 617 and HJ 2 which have closer relationship and genetic background to Criollo rather than Forastero which in this experiment was represented by Amelonado, Upper Amazona and Lower Amazona. This result supports the report on cocoa planting released by Mawardi (1982) who mentioned that the first

\begin{tabular}{|c|c|}
\hline ICS-06 & geaaagaaga. \\
\hline$S C A-6$ & geaaagaagaagc|stctttacceagtagcgaagagettgaaccaagatttctagatgga \\
\hline Criol10-22 & gcaaagaagaagc|atcttttacccagtagcgaagagcttgaaccaagatttctagatgga \\
\hline EET -64 & geaaagaagaagcatcttttacccagtagcgaagagcttgaaccaagatttctagatgga \\
\hline ICS-01 & gcaaagaagaadchtcttttacccagtagcgaagagettgaaccaagatttctagatgga \\
\hline Amelonado & gcaaagaagaagc|atcttttacccagtagcgaagagettgaaccaagatttctagatgga \\
\hline ICS -39 & gcaaagaagaagchtcttttacccagtagcgaagagcttgaaccaagatttctagatgga \\
\hline SULAWESI 1 & GCAAAGAAGAACCATCTTTTACCCAGTAGCGAAGAGCTTGAACCAAGATTTCTAGATGGA \\
\hline DRC16 & CCANAGAAGAAdCFTCTTTYACCAGTAGCGAAGAGCTTGAACCARGATTCTAGATGGA \\
\hline KW617 & GCAAAGAAGAAđ CATCTTTTACCCAGTAGCGAAGAGCTTGAACCAAGATTTCTAGATGGA \\
\hline PNT16 & GCAAAGAAGAAdC ATCTTTYACCCAGTAGCGAAGAGCTTGAACCAAGATTTCTAGATGGA \\
\hline ICCRI02 & GCAAAGAAGAAdC ATCTTTTACCCAGTAGCGAAGAGCTTGAACCAAGATTTCTAGATGGA \\
\hline $\mathrm{MCCO} 2$ & GCAAAGAAGAAdC|ATCTTTTACCCAGTAGCGAAGAGCTTGAACCAAGATTTCTAGATGGA \\
\hline HJ2 & GCAAAGAAGAAdCATCTTTYACCCAGTAGCGAAGAGCTTGAACCARGATTTCTAGATGGA \\
\hline DR2 & GCAAAGAAGAACC ATCTTTTACCCAGTAGCGAAGAGCTTGAACCAAGATTTCTAGATGGA \\
\hline $\mathrm{MCCO} 1$ & 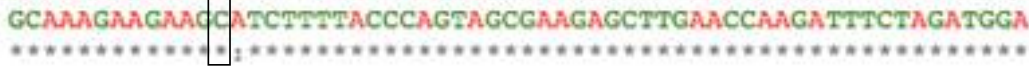 \\
\hline ICS-06 & agaaa paatecgttcaagaaagactccagagatgttgatcgt \\
\hline SCA-6 & tgctctattttccatagaaa a paattcgttcaagaaagactcclaglagatgttgatcgt \\
\hline Criol10-22 & tgctctattttccatagaaat. haattcgttcaagaaagactcclaglagatgttgatcgt \\
\hline EET-64 & tgctctatttttecatagaaa|taattcgtteaagaaagactecag aagatgttgatcgt \\
\hline ICS-01 & tgctctattttecatagaaa|t haattegttcaagaaagactcelag|agatgttgategt \\
\hline Amelonado & tgctctattttccatagaaat|haattcgttcaagaaagactcclagagatgttgatcgt \\
\hline $1 \mathrm{Cs}-39$ & tgctctattttccatagaaat| paattcgttcaagaaggactcclaglagatgttgatcgt \\
\hline SULAWESI 1 & 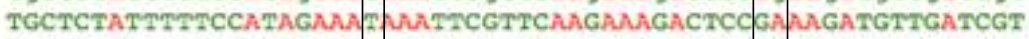 \\
\hline DRC 16 & TGCTCTATTTTCCATAGAAAT| LATTCGTTCAAGAAAGACTCCACAAGATGTTGATCGT \\
\hline KW617 & TGCTCTATTTTTCCATAGAAAFAATCGTTCAAGAAAGACTCCAGAAGATGTTGATCGT \\
\hline PNT16 & TGCTCTATTTTCCATAGAAA \\
\hline ICCRIO2 & 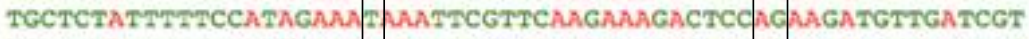 \\
\hline $\mathrm{MCCO} 2$ & TGCTCTATTTTTCCATAGAA I. \\
\hline HJ2 & TGCTCTATTITCCATAGAAAF|AAMTCGTTCAAGAAAGACTCCAGAAGATGTTGATCGT \\
\hline DR2 & TGCTCTATTTTCCATAGAAA EAATTCGTTCAAGAAAGACTCCACAAGATGTTGATCGT \\
\hline $\operatorname{MCCO} 1$ & 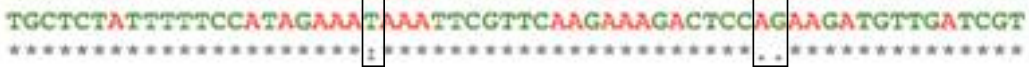 \\
\hline
\end{tabular}

Figure 2. Differences in the nucleotide base arrangement based on the multi alignment of the matK on the cocoa plant 


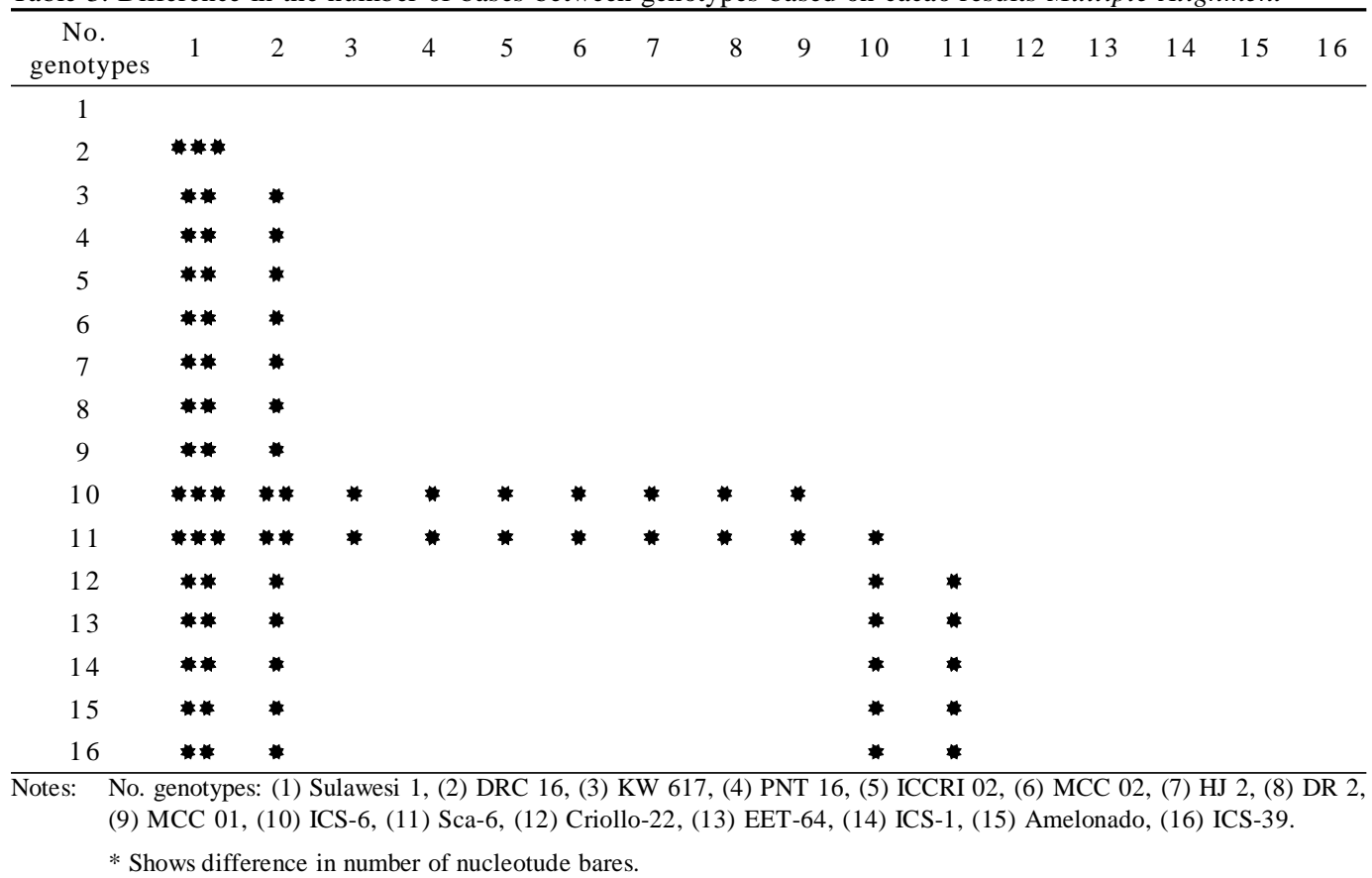

cocoa breeding procedure was done by Van Hall in 1912 using the Criollo as the female parent and Forastero as the male parent. The mat $K$ gene is a chloroplast gene which is maternally inherited, resulting to a progenic closeness and genetic background between the samples and the female parent beans. Character inheritance from the parents to the scions might occur in two mechanisms; chromosomal (nucleous) and extrachromosomal. Extrachromosomal inheritance is controlled by the gene outside the nucleous. Extrachromosomal inheritance might occur in the form of cytoplasmic inheritance if the genetic factors come from outside the nucleous. Genetic factors can be only transferred through cytoplasm and they last for several generations (Sastrosumarjo et al., 2013). The plastids in plants can be inherited from the parent plants to the scions in three ways; maternal, parental and biparental, yet the plastids in plants with flower is mostly inherited maternally (Mogensen, 1996). The DNA plastids inheritance in plants is controlled by methylation process within a specific site of a DNA in a maternal organel that prevents degradation form occurring in the zygote (Hu et al., 2005).

It is important to deterime the genotype identity of the parent clones of cocoa plants to make sure that they bring Criollo genes that produce white cocoa beans. Bartley (2005) explained that white cocoa beans are produced by two pairs of recessive genes (aa). It is believed that most of cocoa plants in Indonesia come from Trinitario type which is known to bring Criollo gene $(a)$ and Forastero $(A)$, which make it feasible to obtain gene $a a$ that procudes white beans cocoa through cross-pollination. Furthermore, if the the identity of the parent plants is not identified, it would be difficult to obtain cocoa plants with white beans because when the genotype of Forestero $(A A)$ meets the Triniatrio with $A a$ genotype, double recessive genes would not be obtained and white beans cannot be produced.

Beside genetic determination, genetic gap is also an important factor to consider 


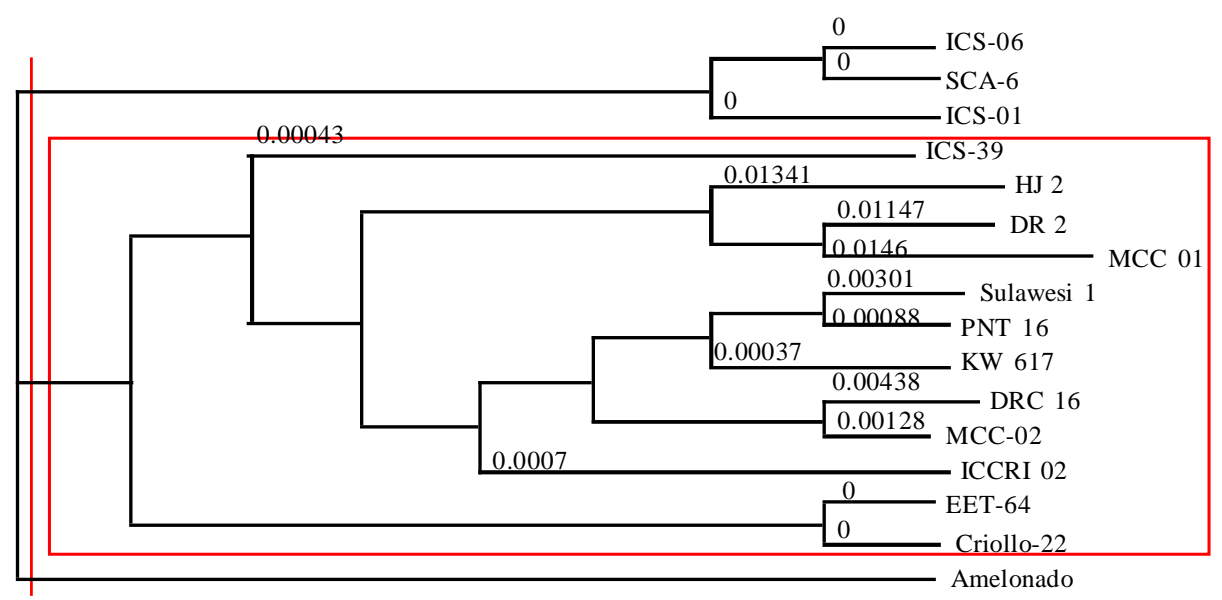

Figure 3. Phylogenetic chart of several cocoa genotypes based on the sequence base nucleotide $\mathrm{matK}$

in determining the parent plants. Result of previous research done by Susilo et al., (2011) showed that PNT 23 was a genotype of Java Criollo group which had the closest relationship with Criollo 22. Phylogenetic analysis using $m a t K$ gene was intended to obtain better edel cocoa seeds with better resistance to VSD using parent plants with the closest genetic gap that were DR $2 \times$ MCC 01, PNT 16 x Sulawesi 1/KW 617, DRC $16 \mathrm{x}$ MCC 02. On the other side, to produce better genetic variety, parent plants should have the most distant genetic gap. It is also important in selecting the best parent plants, the characteristics of the plants including the taste of the beans should be highly considered in order to maintain the quality of the edel cocoa which is famous for its fine flavor taste.

\section{CONCLUSIONS}

The primer Mac 02 and Mac 09 can be used to amplify the maturase $\mathrm{K}$ gene $(m a t K)$ in cocoa plants with a relatively high homology level of around 90-100\%. Most of cocoa plants in Indonesia inherit their genetic background from the female Criollo as shown by the result of maturase $\mathrm{K}$ gene analysis (matK). Parent plants selection to improve the plant resistance to VSD can be carried out using the parent plants with a close genetic gap, namely DR $2 \times$ MCC 01 , PNT 16 x Sulawesi 1/ KW 617, DRC 16 x MCC 02. On the other hand, to obtain various genetic diversity, plants with distant genetic gap can be used as the parent plant but the quality taste of the beans should remain the main consideration.

\section{REFERENCES}

Anita-Sari, I.; A.W. Susilo \& S. Mawardi (2015). Seleksi dan pemuliaan kakao. In: Kakao, Sejarah, Botani, Proses Produksi, Pengolahan, dan Perdagangan. Gadjah Mada University Press. Indonesia.

Anita-Sari, I.; A.W. Susilo \& B. Setyawan (2016). Chromatographic identification of leaf color characteristics on fine-flavor and bulk cacao as selection indicator. Pelita Perkebunan, 32, 1-9.

Baker, N.R.; K. Hardwick \& P. Jones (1975). Biochemical and physiological aspect of leaf development in cocoa (Theobroma cacao). II. Development of chloroplast ultrastructure and carotenoids. New Phytologist, 75, 513-518.

Bartley, B.G.D. (2005). The Genetic Diversity of Cocoa and Its Utilization. CABIPublishing. London, UK.

Chase, M.W.; D.E. Soltis; R.G. Olmstead; D. Morgan; D.H. Les; B.D. Mishler; 
M.R. Duvall R.A. Price; H.G. Hills; Y.L. Qiu; KA. Kron; J.H. Rettig; E. Conti; J.D. Palmer; J.R. Manhart; K.J. Sytsma; H.J. Michaels; W.J. Kress; K.G. Karol; W.D. Clark; M. Hedren; B.S. Gart; R.K. Jansen; K.J. Kim; C.P. Wimpee; J.F. Smith; G.R. Furnier; S.H. Strauss; P.S. Soltis; S.M. Swesen; S.E. Williams; P.A. Gradek; C.Q. Quinn; E.L. Eguiarte; S.C.H. Barrett; S. Dayanandan \& V.A. Albert (1993). Phylogenetics of seed plants: and analysis of nucleotide sequences from the plastid gene $r b c L$. Annals of the Missouri Botanical Garden, $80,528-580$.

Didriksen, A. (2010). Molecular Biology and Physiology of Isolated Chloroplast from the Algae Vaucheria. Thesis. University of Tromso, Norwegia.

Enan, M.R. \& A. Ahmed (2012). DNA barcoding based on plastid $m a t K$ and DNA polymerase for assessing the genetic identity of date (Phoenix dactylifera $\mathrm{L}$.) cultivars. Gen and Molecular Research, 13, 3527-3536.

Fatchiyah, L.; A. Estri; W. Sri \& R. Sri (2011). Biologi Molekular Prinsip Dasar Analisis. Erlangga. Jakarta.

Fuse, S. \& M.N. Tamura (2000). A phylogenetic analysis of the plastid matK gene with emphasis on Melanthiaceae sensu lato. Plant Biology, 2, 415-427.

Hu, Y.; Q. Zhang \& Sodmergen (2005). Potential cytoplasmic inheritance in Wisteria sinensis and Robinia pseudoacacia (Leguminosae). Plant and Cell Physiology, 46, 1029-1035.

Immanisa, S. (2016). Identifikasi Gen Maturase $K$ (matK) pada Kakao (Theobroma cacao L.) Trinitario (Asal Lampung dan Sumatera Barat) dan Forastero (Asal Sulawesi dan Introduksi). Skripsi. Universitas Indonesia. Jakarta.

Kalangi, C.; V.S. Kamu \& M. Kumaunang (2014). Barcode DNA tanaman leilem (Clerodendrum minahassae L.) berdasarkan gen matK. Jurnal "MIPA UNSRAT” Online, 3, 108-112.
Kress, W.J. \& D.L. Erickson (2007). A two-locus global DNA barcode for land plants: The coding $r b c$ L gene complements the non-coding $\operatorname{trn} H$-psbA spacer region. PloSONE, 2, 508-513.

Mawardi, S. (1982). Tujuh puluh tahun pemuliaan tanaman cokelat di Indonesia. Menara Perkebunan, 50, 17-22.

Mogensen, H.L. (1996). The hows and whys of cytoplasmic inheritance in seed plants. American Journal of Botany, 87, 383-404.

Motamayor, J.C.; A.M. Risterucci; P.A. Lopez; C.F. Ortiz; A. Moreno; J.S. Brown \& R.J. Schnell (2008). Geographic and genetic population differentiation of the Amazonian chocolate tree (Theobroma cacao L.). PlosONE, 3, 10.

Suhendi, D.; S. Mawardi \& H. Winarno (2004). Daya hasil dan daya adaptasi klon harapan kakao mulia. Pelita Perkebunan, 20, 54-65.

Susilo, A.W.; S. Mawardi \& Sudarsianto (2009). Keragaan daya hasil klon kakao (Theobroma cacao L.) Sca 6 dan DRC 15 tahan penyakit pembuluh kayu. Pelita Perkebunan, 25, 76-85.

Susilo, A.W.; D. Zhang; L.A. Motila; S. Mischke \& L.W. Meinhardt (2011). Assessing genetic diversity in Java fine-flavor cocoa (Theobroma cacao L.) germplasm by using simple sequence repeat (SSR) markers. Tropical Agriculture Development, 55, 84-92.

Sastrosumarjo, S.; S. Sujiprihati; M. Syukur; S.I. Aisyah; Y. Wahyu \& R. Yunianti (2013). In: Sitogenetika Tanaman. M. Syukur \& S. Sastrosumarjo (Eds.). IPB, Bogor.

Van Hall, C.J.J. (1913). Eerste Verslag van de Cacao-Selectie. Mid-Java, Mededelingen Proefstation.

Yeoh, H.; D.K. Chung \& P.J. Fritz (1990). Theobroma cacao chloroplast DNA: isolation, molecular cloning, and characterization. Café Cacao, 3, 173-178.

$$
* * 0 * *
$$

